Humanitarian and Socio-Economic Sciences Journal 2(13) (2019) 8-11

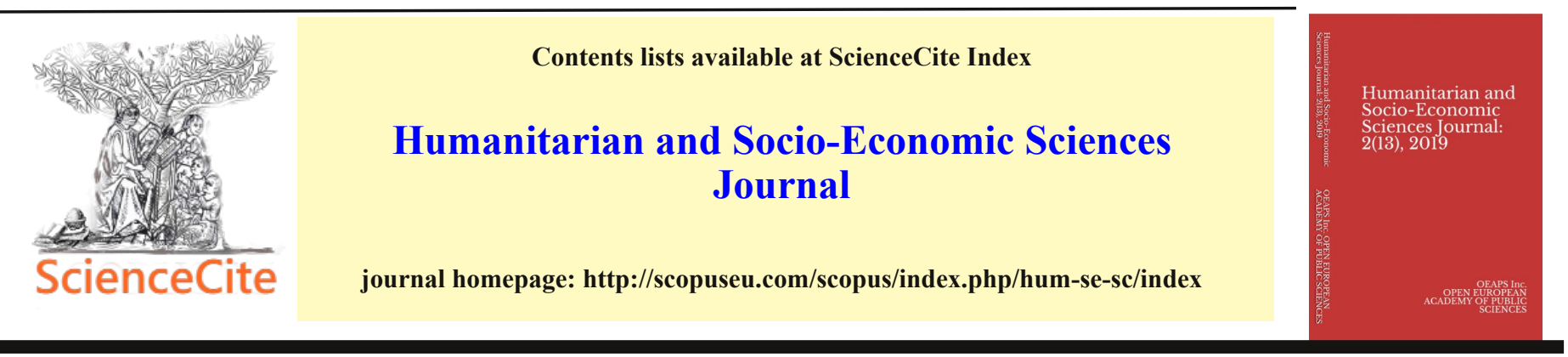

\title{
The banking sector in Uzbekistan
}

Akromov Azizjon ${ }^{1 *}$, Azlarova Mushtariybegim², Mamataliev Bobur ${ }^{2}$, Koriev Azimkhon²

${ }^{1}$ Singapore management and development Institute in Tashkent

${ }^{2}$ Tashkent state university of economics

\section{ARTICLE INFO}

\section{ABSTRACT}

Article history:

Received January 17, 2019

Accepted January 21, 2019

Available online February 14, 2019

JEL classifications: No

УДК 5277.307

Keywords: banking sector,

exportimport, resources, competencies, National Bank of Uzbekistan
The banking sector plays a significant role in a contemporary world of money and economy. Today 29 banks with 826 regional branches and more than 2,300 minibanks, over 9,000 banking infrastructures, and 84 nonbank credit organizations operate in the country.
(C) 2019 The Author. Published by OEAPS Inc. This is an open access article under the CC BY-NC-ND license (http://creativecommons.org/licenses/by-nc-nd/4.0/).

\footnotetext{
*Corresponding author.E-mail address: shakhzodbeksh@gmail.com
} 


\section{Introduction}

The banking sector is increasingly becoming competitive in Uzbekistan.

The banking sector plays a significant role in a contemporary world of money and economy. Today 29 banks with 826 regional branches and more than 2,300 mini-banks, over 9,000 banking infrastructures, and 84 non-bank credit organizations operate in the country.

On top of what they are doing and thus maximize the share of this sector.

Central Bank is economically independent institution exercising its costs from its own revenues. Legal status, tasks, functions, powers, principles of organization and activity of the Central Bank of the Republic of Uzbekistan are determined by the Constitution of the Republic of Uzbekistan, the Law of the Republic of Uzbekistan "About the Central Bank of the Republic of Uzbekistan" and other legislative acts. The National Bank of the Republic of Uzbekistan for Foreign Economic Activity was established under the Decree of the first President of Uzbekistan, I. Karimov in September 1991. The history of the Bank reflects the dynamics of the country's economic development during the years of independence. The National Bank serves over $70 \%$ of the total foreign trade turnover of Uzbekistan, with such mechanisms of export-import crediting as: issuing guarantees for the return of advance payments, execution of contracts; discounting of bills; factoring; direct lending by the bank to Uzbek exporters; project financing; export-import financing with participation of export- credit agencies.

Key success factors refer to those factors which are important to future competitive success of industry members. These factors include product attributes, competitive capabilities, resources, competencies, market achievement etc. Latest technology plays a huge role in modern banking industry. It helps in introducing innovative products according the demand of consumer. In Uzbekistan, we have 7 million mobile banking users, from which 834661 are customers of NBU. Mobile banking can make banking convenient for customer and also impact their banking transaction. It can be used not only for banking for customers also for paying bills, booking movie tickets, mobile transaction, fund transfer, investment, balance enquiry, paying bills through mobile banking. All the banks that are licensed and have branch in Uzbekistan are allowed to provide mobile banking services to their clients. This is the main reason for developing in this area in the future mobile banking users will increase significantly and this will help customers to get better services and also help banks to increase their profit.

The Questions of the survey, which is going to be held, is, "Should the CB and other banks of Uzbekistan, implement latest technologies, into its system?" The answer will be started from "literature review part, where will be shown some ideas of different people, then the method of gaining required data, and finally research will be concluded.

With the tremendous use of mobile in Uzbekistan, mobile services became a prospective alternative for the banking sector. This growth is supported by literature as well. Mobile banking transactions are gaining importance and having huge potential due to availability and facility to do transactions anytime and anywhere (Rugimbana, 1995). Banks should understand this trend and use updated methods. Various studies explained that banks need innovations and creativity in their bank facility to gain competitive edge (Vyas, 2009; Rao et al. 2003). Banks need to rethink about innovation in mobile banking beyond online banking and make mobility self- sufficient to satisfy customer needs and become powerful delivery control of their finances. This theory is confirmed by other researchers also and assures a bright future of mobile banking. (Gupta, 1999; Pegu, 2000; Dasgupta, 2002). 
Millions of investors are using cheaper handsets to make voice calls and do text in their daily lives. But still millions of new users of mobile cells are without the access of financial services in developing scenario. This is the important discussion point among various researchers (Saxena D, Kammani \& Hundewale, 2012; Lin, 2010). They explained that banks should create awareness among customers and increase their customers by targeting non-online banking customer who have mobile phones but may not be using internet for banking, thus creating potential for mobile banking (Vyas 2009). Data also shows that customer in urban/metro area use mobile banking mostly to check account balance and followed by viewing last three transactions. Thus, constant and increasing use of mobile banking may encourage customers to use other facilities of bank (Karjaluoto et al. 2002).

Hypothesis 1: We think implementing innovations in mobile banking and improving mobile banking help NBU to gain competitive edge.

Banks should identify the benefits of mobile banking for users. In this domain, cost is one of the most significant factors which impacts mobile banking usage of cutomers (Sadi \& Noordin, 2011). In their study, Sadi and Noordin (2011) found that customer attitude was correlated negatively with cost. Their intention to use mobile banking services decreases with increase cost; therefore, customer must be aware about cost saving feature of mobile banking services through awareness. This research is also supported by Singh, Srivastava and Srivastav (2010), who briefly explained that cost incurred by the customers have a negative impact on their intention to do mobile banking transactions. Mobile banking device is considered to be cost effective option for customers to manage transactions, get account information and do payments (Clark, 2008). Mobile device provides handiness, immediate response and customized products to consumers.

Hypothesis 2: Stating surefire price for banking services of mobile banking will increase the number of customers.

Mobile banking not only offers facilities like balance check, or do transactions they are also affecting customer behavior. Integration of banking with their personal mobile devices, customers are engaging themselves in apps more than even. Reason behind this is mobile apps allow customers to avail banking facilities without physical presence in branch. Customers can also handle their money with a click. This facility is encouraging customers to use mobile banking and provide real life experience. They can carry out their key transactions on smartphones to save cost and time. Mobile banking is convenient for them to use and is being used on a regular basis. The habitual use of the apps helps banks to have consumer on their display 30-40 times in a month (Jones W, 2014).

Hypothesis 3: Identifying customers behavior and simplifying mobile banking will help to increase number of transaction and income.

This study will help to understand what is the customers expectation, perception and experience about mobile banking system of National Bank of Uzbekistan. It will help to understand customer demand, wishes, meet the demand and improve mobile banking system of NBU. Survey research method will be used through questionaries' and qualitative data collection research method will be used through case study and observation to collect relevant data. It's been claimed by many authors that's survey very efficient way of data collection. Survey questionnaire will be send to the customers of NBU. Data will be collected first in three regions Tashkent, Samarkand and Khiva.

Data which will be collected will be analyzed by using factor analysis. Factor analysis is used to select relevant factors for the study and remove or add insignificant items for mobile banking.

The factor analysis will contain 7 factors which are awareness, value addition, user friendly, app 
compatibility, feasibility, security accessibility and reliability will be conducted to determine features of mobile banking services.

Factor 1: Awareness: It will assesse the awareness level of consumer about mobile banking services and features.

Factor 2: Value additions: This factor will judge the new schemes and benefits provided under mobile banking.

Factor 3: User friendly: This factor will include statements which explain the friendliness of mobile app and structure.

Factor 4: App-compatibility: This factor assessed the effectiveness and compatibility of mobile banking system.

Factor 5: Feasibility: This factor will show the viability of the mobile banking system.

Factor 6: Security: Under this factor, we will analyze the security of the app from virus or hacking.

Factor 7: Accessibility: This factor will determine the convenience of mobile app. This factor will tell us the handiness feature of mobile banking app.

Ethical consideration

People who are willing to participate and cooperate during the research will be informed about the evaluating will be conducted, and it is promised to keep their identity confidential. Also anonymity is guarantied to the requiring sources of information. Surveys will be coercion free. No harm, both physical and mental will not effected to the banks and bank workers, and anyone who is involved into the research.
Reference

1. Clark, A. (2008). Mobile banking \& switching. pp. 125-140.

2. Dasgupta, P. (2002). Future of E-Banking in India. Retrieved from www. projectshub.com on 10 july 2015

3. Gupta, D. (1999). Internet banking: where does India stand? Journal of Contemporary Management, 2 (1).

4. Jones, W. (2014) Mobile banking apps: Convenience Triggers shift in User Behaviour.

5. NBU. (2018). O банке. [online] Available at: https://nbu.uz/about-bank/ [Accessed 5 Nov. 2018]. Pegu, R. (2000). Net-banking is fast becoming popular. The week

6. Cbu.uz. (2018). Количество пользователей дистанционным банковским обслуживанием. [online] Available at: https://cbu.uz/ru/statistics/ paysistem/2018/10/150492/ [Accessed 5 Nov.2018].

7. Karjaluto, H. (2002). Selection criteria for a mode of bill payment: Empirical investigation among Finnish bank customers.

8. Rugimbana, R. (1995). Predicting ATM usage: The relative importance of perceptual and demographic factors. International Journal of Bank Marketing, 13(4), 18-31.

9. Sadi, A.H., \& Noordin, M.F. (2011).Factorsinfluencing the implementation of mcommerce: An exploratory Analysis. Personal and Ubiquitous Computing, 401-412.

10. Saxena, D. (2010). Alternate banking delivery channels. Accounting Education. Sharma, P., \& Singh, P. (2009). Users 'perception about mobile banking- with special reference to Indore $\&$ around. Review of Business \& Technology Research, 2(1), 14. 